root potential would be governed by the time constant of the mernbrane of the terminal nerve fibres of that dorsal root, and it would be these terminals that are specifically affected by nembutal. The partial destruction of the dorsal root potential by a maximum volley in that root suggests that the impulses do not penetrate to all the central terminal nerve fibres of that root. This suggestion recalls the findings of Renshaw ${ }^{6}$ and Lloyd ${ }^{7}$ that an antidromic impulse in a ventral root fibre may fail to spread over the surface of the motoneurone of that fibre, block apparently occurring at the axon hillock.

JoHN C. ECCLES.

Physiology Department,

Medical School,

Dunedin, N.Z.

June 27.

${ }^{1}$ Barron, D. H., and Matthews, B. H. C̀., J. Physiol., 92, 276 (1938).

${ }^{2}$ Sonnet, V., and Bremer, F., Compt. Rend. Soc. Biol., 127, 806, 812 (1938).

3 Eccles, J. C., Nature, 153, 432 (1944).

'Cole, K. S., and Curtis, H. J., J. Gen. Physiol., 22, 649 (1939).

'Osterhout, W. J. V., "Injury, Recovery and Death in relation to Conductivity and' Permeability" (Philadelphia, 1922).

- Renshaw, B., J. Neurophysiol., 5, 235 (1942).

' Lloyd, D. P. C., J. Neurophysiol., 6, 143 (1943).

${ }^{8}$ Guttman, R., J. Gen. Physiol., 22, 567 (1939).

\section{Mechanism of Burrowing in Arenicola marina $\mathrm{L}$.}

If a living lugworm is put on the surface of wet sand or mud, it curves its head downwards and burrows in. During the burrowing act (which was described in detail by Just ${ }^{1}$ ), the proboscis is extruded and withdrawn, wave-movements of a characteristic kind travel forwards along the body, and the notopodia are directed backwards.

According to many authorities, the lugworm swallows sand as it burrows. Thus Stannius ${ }^{2}$ wrote: "Legt man eine ausgegrabene Arenicola auf eine von Seewasser etwas bedeckte sandige Stelle des Ufers, so fängt sie alsbald an, eine Röhre im Sande sich zu bohren. . . . Die Röhren entstehen aber nicht auschliesslich dadurch, dass die Würmer den Sand oder den Schlamm an die Seite drücken, sie verschlingen vielmehr beim Bohren beständig Sand; der ganze Darmkanal wird davon angefüllt, und ehe der hinterste Theil des Thieres die Oberfläche des Bodens ganz verlässt, wird der verschluckte Sand durch den After wieder entleert." Ashworth ${ }^{3}$ concludes a description of burrowing with the words "By these means, a passage is eaten and forced through the mud".

When those passages were written, the mode of life of the lugworm was not well understood. In particular, burrowing and feeding were supposed to be one and the same process. More recent work, however, indicates that the two are quite distinct" The worm is now believed to excavate an $L$-shaped gallery, and to lie with its head at the blind end, eating the surrounding mud. I therefore made the following experiments, to find out whether significant amounts of sand or mud are in fact swallowed during burrowing.

(1) Weighing experiments. Lugworms were first weighed, then allowed to burrow until only the tip of the tail could still be seen, then dug out and weighed again. The anus was watched, and, if the worm defæcated during burrowing, that particular experiment was discarded. Usually, however, defæcation did not occur. Of the successful experiments, two were done on the beach at Bangor, the worms being allowed to burrow as soon as they were dug up, and the rest in the Department of Zoology of the University of North Wales, using muddy sand, from the beach. Generally there was a very slight loss of weight during burrowing (see table). The density of the wet, muddy sand was about $1 \cdot 9$, so it seems that significant amounts cannot have been swallowed.

\begin{tabular}{|c|c|c|c|c|}
\hline \multirow{3}{*}{ Situation } & \multirow{2}{*}{ Worm No. } & \multicolumn{3}{|c|}{ Weights (gm.) } \\
\cline { 3 - 5 } & $\begin{array}{c}\text { Before } \\
\text { burrowing }\end{array}$ & $\begin{array}{c}\text { After } \\
\text { burrowing }\end{array}$ & Difference \\
\hline Beach & 1 & $4 \cdot 0$ & $3 \cdot 8$ & $-0 \cdot 2$ \\
& 2 & $7 \cdot 5$ & $7 \cdot 3$ & -0.2 \\
\hline Laboratory & 3 & $3 \cdot 8$ & $3 \cdot 8$ & $0 \cdot 0$ \\
& 4 & $7 \cdot 0$ & 6.9 & $-0 \cdot 1$ \\
& 5 & $8 \cdot 2$ & $8 \cdot 1$ & $-0 \cdot 1$ \\
& 6 & $12 \cdot 3$ & $12 \cdot 3$ & $0 \cdot 0$ \\
\hline
\end{tabular}

(2) Dissection experiments. Five worms were kept in clean sea water in the laboratory for from three to four weeks. Three of them were then allowed to burrow into sand from the beach, as described above, then dissected under 8 per cent magnesium chloride, which acts as a narcotic 5 . The other two were dissected without preliminary burrowing. In the two controls, there was no trace of sand in any part of the gut. In the worms which had burrowed, small amounts of sand were found in the cesophagus, but there was none in any other part of the gut. One of the three had a single, minute mass of sand, comprising only some half-dozen sand-grains; the second had a single, compact mass, 2-3 c.mm. in volume; and the third had most of its osophagus incompletely filled with a cylinder of sand. In all cases, the amounts ingested were negligibly small, compared with the volume of a whole worm.

Clearly, the idea that Arenicola passes through the sand like an animated cork borer is fallacious. Burrowing is achieved by thrusting the sand, or mud, aside; very little, if any, is taken in through the mouth. The proboscis is used in burrowing, and also, presumably, in feeding ${ }^{6}$, so it appears to be capable of widely different types of action.

In conclusion, a note may be added about the remark of Stannius ${ }^{2}$, quoted above, that defæcation accompanies burrowing. I saw defæcation during burrowing in two of four worms on the beach, and never in the laboratory. The worms used in the laboratory had been kept in clean water for a couple of days at least, and had partly or completely emptied their intestines. I think it likely that the defæcation occurs only in replete worms, as a pressure effect of some kind incidental to burrowing. Perhaps those which defæcated would shortly have done so in any case, even if they had not been disturbed.

Department of Zoology,

$$
\text { G. P. Whelis. }
$$

University College,

London.

July 23.

1 Just, B., Z. vergl. Physiol., 2, 155 (1925).

${ }^{2}$ Stannius, H., Muller's Arch., 352 (1840).

${ }^{3}$ Ashworth, J. H., "Arenicola", L.M.B.C. Memoirs, XI (1904).

*Thamdrup, H. M., Medd. Komm. Havundersøg., Kbh., 10, 2 (1935).

${ }^{5}$ Ledingham, I. C., and Wells, G. P., Nature, 150, 121 (1942).

- Wells, G. P., J. Exp. Biol., 14, 117 (1937). 